\title{
CHAPTER 10 \\ ORGANIZATION OF ACCOUNTING AND CONTROL OF EQUITY IN AGRICULTURAL ENTERPRISES
}

\section{Krukovska O. V.}

\section{INTRODUCTION}

Reforming the accounting and financial reporting systems required by both internal and external users is an integral part of measures aimed at introducing market-oriented economic relations. The well-managed definition of accounting in accordance with the changes taking place in the organization and practice, enhances the role of accounting as the main means of obtaining reliable information for making economically justified decisions and risk warnings in the production and economic activity of enterprises, in the tax system, in the obligations of long-term, current and billing, balance sheet, preparation of financial reporting, etc. Particularly acute is the problem of rational accounting organization with the transition of domestic enterprises to national standards. After all, it is the nature of management accounting that determines the nature of management decisions and their effectiveness in improving the financial condition of the company. Analyzing the current state of accounting at Ukrainian enterprises, it should be noted that according to the Law of Ukraine «On Accounting and Financial Reporting in Ukraine» every enterprise, regardless of organizational and legal form and types of activity, must keep a continuous accounting from the date of its registration to liquidation. Responsibility for the organization and accounting is allocated to the owner of the enterprise, institution or organization or its authorized body (official), which executes the management of the enterprise.

The purpose is to investigate accounting, analysis and control of equity and to identify ways to improve it. To achieve this purpose it is necessary to solve the following objectives:

- to disclose the nature and content of the company's equity;

- to carry out the review of the legal documents regulating the accounting of the equity of the enterprise;

- consider the features of accounting, analysis and control of equity at the enterprise; 
- develop ways to improve accounting, analysis and control of equity at the enterprise.

The subject of the research is theoretical and methodological and applied problems of accounting, analysis and control of the equity of the enterprise.

The scientific novelty of the obtained results is to clarify and recommend the implementation of proposals for improving the accounting and auditing of the formation and functioning of equity of agricultural enterprises of various organizational and legal forms of management. The scientific novelty is determined by the following basic provisions: the essence and definition of the category «equity» and the composition of its elements as an object of accounting in agricultural enterprises are specified; the concept of accounting of equity and peculiarities of its application in agricultural enterprises of different forms of ownership in accordance with the legal requirements and legal regulation of property relations are substantiated; the method of accounting the formation of share capital of agricultural production cooperatives at the expense of introductory, share and additional contributions, as well as the method of accounting the share capital of farm enterprises.

\subsection{Theoretical and methodological foundations of the organization of accounting and audit of equity of agricultural enterprises}

The property of the enterprise consists of different objects of accounting: holders of ownership rights of individual entities. The rights of each owner to the property of the enterprise and to participate in its profits are determined by the share and form of invested funds. They should be clearly reflected in the accounting report based on the relevant documents. Equity is a guarantee for the protection of property rights of an enterprise, an indicator that characterizes solvency, creditworthiness, availability of funds and the functioning of a utility company.

The essence of the economic category of «capital» has been researched by scientific thought for many centuries. The original meaning of the term «capital» (from Latin «capitalis») means the main, the basic. Later, in the German and French languages, this term began to denote the principal property or the principal sum of money.

Capital is characterized by the following features: it is the main factor of production, characterizes the financial resources of the company, which are profitable, it is the main source of formation of 
owners' well-being, it is the main indicator of the market value of the enterprise, its dynamics is an important «barometer» of the level of efficiency of economic activity of the enterprise. The first scientific definition of capital was given by Aristotle. He linked its essence, on the one hand, with property, with possession, on the other hand, with the art of providing a fortune, or with such an activity that is aimed at making a profit on the investments made.

In further studies, capital was considered: as a set of means of production that bring income to the owner of these funds; as a stock that is used for economic purposes and generates income; as a set of things without which production could not take place, but which are not a free gift of nature. In the above definitions, according to A.M. Poddierohin, the capital category is associated with the physical form and does not take into account cash capital, which cannot be identified with the means of production and intended for their acquisition, to ensure the continuous movement of capital in the fields of production and circulation. If we consider capital as a kind of investment that makes it possible to generate income, then it should also include costs that contribute to the future increase in income, i.e. investment in labor.

These approaches to the defining capital can be described as the macroeconomic. From the point of view of the enterprise (at the microeconomic level), capital is the sum of the valuation of property and funds of an entrepreneur that he/she can use for economic needs. The functioning of capital at the microeconomic level can be characterized by the process of its individual cycle, which is carried out according to the scheme (Figure 1):

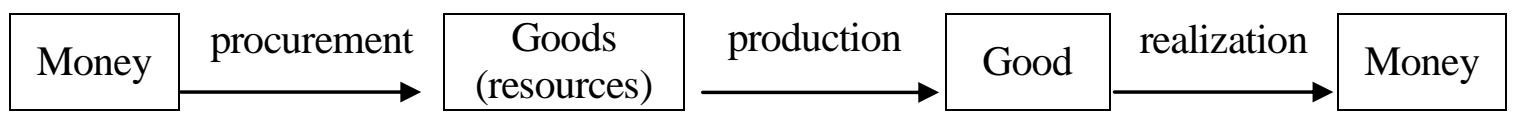

\section{Figure 1. The operation of capital at the microeconomic level}

That is, the capital of any entity consists of three parts: the means of production, finished goods, money and monetary instruments. The enterprise, first of all, has to advance funds for the procurement of factors of production. For this purpose it enters into economic relations with sellers in the market of the means of production and enters the labor market in order to acquire the necessary quantity and quality of labor.

Thus, for a new enterprise, capital begins to move in the sphere of circulation as cash capital. The main function of production capital is 
to bring greater value, that is, to grow itself. In this case, capital takes the form of commodity capital, the main function of which is the sale of goods and the receipt of greater value in cash.

The capital of the enterprise is the main measure of its market value. This role is primarily played by the equity of the enterprise, which is determined by the volume of its net assets and, at the same time, the amount of borrowed funds that contribute to generating additional income ${ }^{1}$. The growth of equity in the dynamics characterizes the level of efficiency of economic activity of the enterprise, its ability to maintain financial equilibrium at the expense of internal sources. The decrease in equity is related to its ineffective, or unprofitable, activity. The great role of capital in the economic development of the enterprise and ensuring the interests of the state, investors, owners and employees determines its importance in the financial activity of the enterprise.

The multifaceted nature of the enterprise classifications, as a consequence, has led to the existence of a large number of areas of classification of the company's equity in the economic literature (Tab. 1).

Table 1

\section{Basic directions of definition of the equity structure in modern economic literature}

\begin{tabular}{|c|c|c|}
\hline No. & Authors & Equity structure \\
\hline 1 & Anthony Robert N. & $\begin{array}{l}\text { - Joint stock } \\
\text { - Reinvested earnings }\end{array}$ \\
\hline 2 & $\begin{array}{l}\text { Welsh Glenn A., } \\
\text { Short Daniel G. }\end{array}$ & $\begin{array}{l}\text { - Authorized capital } \\
\text { - Additional capital } \\
\text { - Retained earnings }\end{array}$ \\
\hline 3 & Sopko V.V. & $\begin{array}{l}\text { - Registered capital } \\
\text { - Unregistered capital } \\
\end{array}$ \\
\hline 4 & $\begin{array}{l}\text { Hendriksen E.S., } \\
\text { Van Breda M.F. }\end{array}$ & $\begin{array}{l}\text { - Amounts paid by shareholders } \\
\text { - Excess of net profit over dividends } \\
\text { - Free income from others }\end{array}$ \\
\hline 5 & $\begin{array}{l}\text { Hendriksen E.S., } \\
\text { Van Breda M.F. }\end{array}$ & $\begin{array}{l}\text { - Face value } \\
\text { — Additional face value paid by shareholders } \\
\text { - Formed as a result of revaluations } \\
\text { — Retained earnings }\end{array}$ \\
\hline
\end{tabular}

${ }^{1}$ Butynets F.F. (2003). Bukhhalterskyi finansovyi oblik: Pidruchnyk dlia studentiv spetsialnosti «Oblik i audyt» vyshchykh navch. zakl. [Accounting Financial: A textbook for students of the specialty «Accounting and Auditing» higher education] 5-e vyd., dop. i pererob. Zhytomyr : PP «Ruta», 726 p. ISBN 966-681-012-5. 


\begin{tabular}{|c|c|c|}
\hline No. & Authors & Equity structure \\
\hline 6 & $\begin{array}{l}\text { National } \\
\text { Accounting } \\
\text { Provisions } \\
\text { (Standards) of } \\
\text { Ukraine }\end{array}$ & $\begin{array}{l}\text { - Actual paid authorized (share) capital } \\
\text { (authorized capital except for unpaid and } \\
\text { withdrawn) } \\
\text { - Additional capital } \\
\text { - Reserve capital } \\
\text { - Retained earnings (+) / Uncovered losses (-) }\end{array}$ \\
\hline
\end{tabular}

Different authors have different approaches to defining and accordingly offer different structure of equity. Some academic economists divide equity into equity invested by shareholdres and created by a joint-stock company during its lifetime. For example, Sopko V.V. proposes the general structure of business equity in the following form: equity of owners (registered and unregistered, i.e. additionally invested by founders), capital created in the course of activity, other additional capital not invested by owners ${ }^{2}$. In domestic practice, joint-stock companies use the components of equity given in the present NP(S)A 1 «General requirements for financial reporting».

The capital of the enterprise can be characterized by the following features: by belonging to the enterprise, sources of capital formation, belonging to the owners of capital, form of ownership, organizational and legal form of raising capital, term of raising capital, forms of stay in the process of circulation, ${ }^{3}$ objects of investment, level of risk, the nature of use in the production process.

By belonging to the company equity and loan capital are distinguished. Equity is a part of the assets (property) of an enterprise, which is formed at the expense of the contributions of the founders and own funds of business entities. Equity information is contained in section 1 of the liability balance sheet. Loan capital is the money that is used to finance the business of an enterprise on the principles of timeliness, return and payment. The main types of loan capital are: bank loans, bond issue, financial leasing. Both equity and loan capital can be generated from internal and external sources.

By nationality, the owners of the capital that make it available for economic use to the enterprise distinguish between national capital and foreign capital invested in the enterprise. Equity and public capital atr distinguished in the form of ownership. This classification of capital is used primarily in the process of forming

\footnotetext{
${ }^{2}$ Kulichenko O. (2004). Vypustit mene, bud laska [Let me out, please]. Debet-Kredyt - 311, p. 25.

${ }^{3}$ Holov S.F. (2000). Bukhhalterskyi oblik ta finansova zvitnist v Ukraini: Navch.-prakt. posibnyk [Accounting and financial reporting in Ukraine]. Dnipropetrovsk, 768 p. ISBN 966-683-033-9.
} 
the authorized capital of the enterprise. According to the organizational and legal form of raising capital, the company allocates joint stock, share capital and individual capital. By the form of being in the process of circulation, the capital of the enterprise is divided into capital in cash, capital in production form and capital in commodity form (Figure 2).

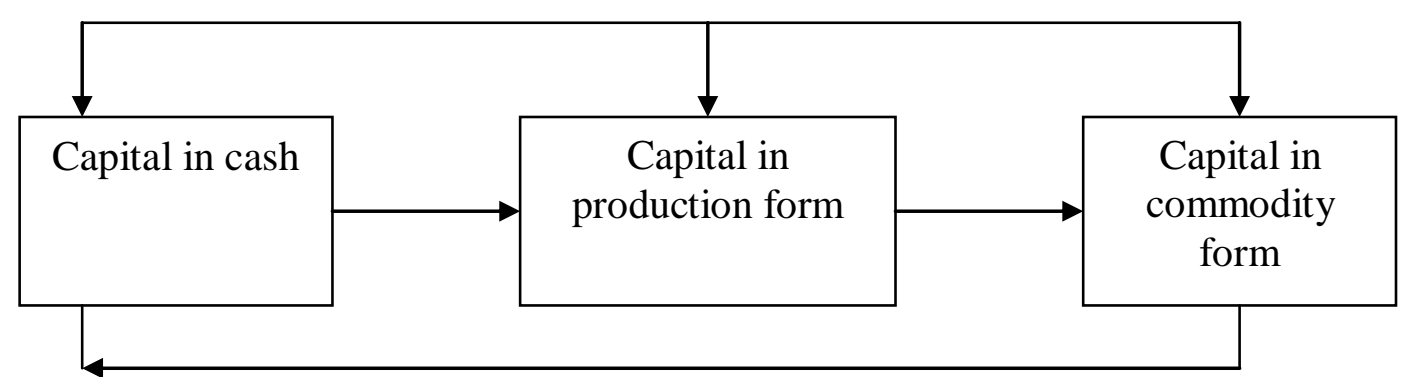

Figure 2. Circulation of capital of the enterprise

Depending on the term for which the capital is raised, long-term capital and short-term capital are distinguished. The long-term capital of the enterprise consists of equity and loan capital with a life period of more than one year. The short-term capital of the enterprise is raised for a period of up to one year and is used in case of financial difficulties that arise due to shortage of working capital.

Depending on the object of investment, the company's fixed capital and its working capital are distinguished. The fixed capital of the enterprise is a set of property values of the enterprise, which repeatedly participate in the process of economic activity and transfer their value to the value of manufactured products in parts. The fixed capital describes the portion of capital used by an enterprise that is invested in all types of non-current assets. The working capital of the enterprise is a set of property values that serve the economic process and is fully used in one production cycle. Therefore, the working capital characterizes the part that is invested in all types of its current assets.

The essence of an enterprise's equity is manifested through its functions. Equity functions are shown in Figure 3.

The equity of the enterprise in the process of its constant movement is characterized by a certain liquidity, which means its ability to be realized at its real market value and to cover at the expense of part of its liabilities in liquidation of the enterprise. 
Long-term fundings, i.e. the disposal of the enterprise for an unlimited long time

Responsibility and protection of creditors' rights, i.e. equity reflected in the balance sheet is for external users a measure of the responsibility of the enterprise, as well as protection of creditors against loss of capital

Compensation for incurred losses, i.e. temporary losses are repaid at the expense of equity

Creditworthiness, i.e. when granting credit, all things being equal, preference is given to companies with lesser debt

Risk financing, i.e. equity is used to finance risky investments that creditors may not agree to

Independence and power, i.e, the size of equity determines the degree of independence and influence of its owners on the enterprise

Distribution of income and assets, i.e. shares of individual owners in the capital are the basis for the distribution of the financial result and property in the liquidation of the enterprise

\section{Figure 3. Equity functions}

At the time of the establishment of the enterprise, the equity is equal to the value of the founders' assets, which are valued at their approved fair value. The use of invested assets allows the founders (owners) to start their business. Further, in the course of the enterprise's economic activity, the amount of equity is constantly changing, and the assets contributed at the date of its establishment can no longer be identified. The amount of equity is affected by the presence and valuation of the assets and liabilities of the enterprise. It can be determined by the basic balance equation. 


\section{ASSETS $=$ OBLIGATIONS + CAPITAL$$
\text { CAPITAL }=\text { ASSETS }- \text { OBLIGATIONS }
$$

The sources of equity formation are: contributions (investments) of the business owners in the form of cash and other assets; donation of property or funds to individuals and legal entities; revaluation of the assets of the enterprise provided that their market value increases; accumulation with subsequent reinvestment of retained earnings. Therefore, it should be noted that in accounting, equity is most often classified according to the sources of creation and the level of responsibility. Thus, according to the sources of creation, equity is divided into two categories: invested (contributed or paid capital); retained earnings.

Equity is the "abstract value of the property; it is neither current market nor any other valuation for its owners, therefore, does not reflect the present value of the rights of the owners of the firm». Equity is significantly affected by the components of an entity's accounting policies that relate to the principles, methods and procedures ${ }^{4}$ selected to recognize and evaluate the elements and items of the balance sheet, including its assets and obligations.

The general concept of «enterprise capital» is understood as its different types, which are characterized by dozens of terms. All this requires appropriate systematization of the terms used. In most detail, according to the main classification features, V.V. Hlushchenko considered some types of the enterprise capital as a whole and equity in particular. The financial and economic vision of the classification of equity proposed can be represented as a scheme (Figure 4).

Authorized (registered) capital and additional (unregistered) capital perform different functions. Thus, authorized capital is the primary source of investment and formation of property of the enterprise. ${ }^{5}$ Unlike additional capital, it provides regulation of property relations and management of the enterprise, its size cannot be smaller than the amount stipulated by law. According to $\mathrm{NP}(\mathrm{S}) \mathrm{A} 1$, the equity of the enterprise is represented by section I of the liability, the result of which reflects the size of this financial indicator. Equity includes the following structural elements (Figure 5):

\footnotetext{
4 Holtsova S.M., Plikus I.I. (2007). Bukhhalterskyi oblik: navchalnyi posibnyk [Accounting]. 2-he vyd., pererob. i dop. Sumy: VTD «Universytetska knyha», 254 p.

Goncharova N.N. (2001). Problemy stanovleniya uchetnoy politiki predpriyatiya v usloviyakh reformirovaniya bukhgalterskogo ucheta [The problems of the enterprise's accounting policy formation in the circumstances of reformation of accounting]. Rehionalni perspektyvy, $286 \mathrm{p}$.
} 


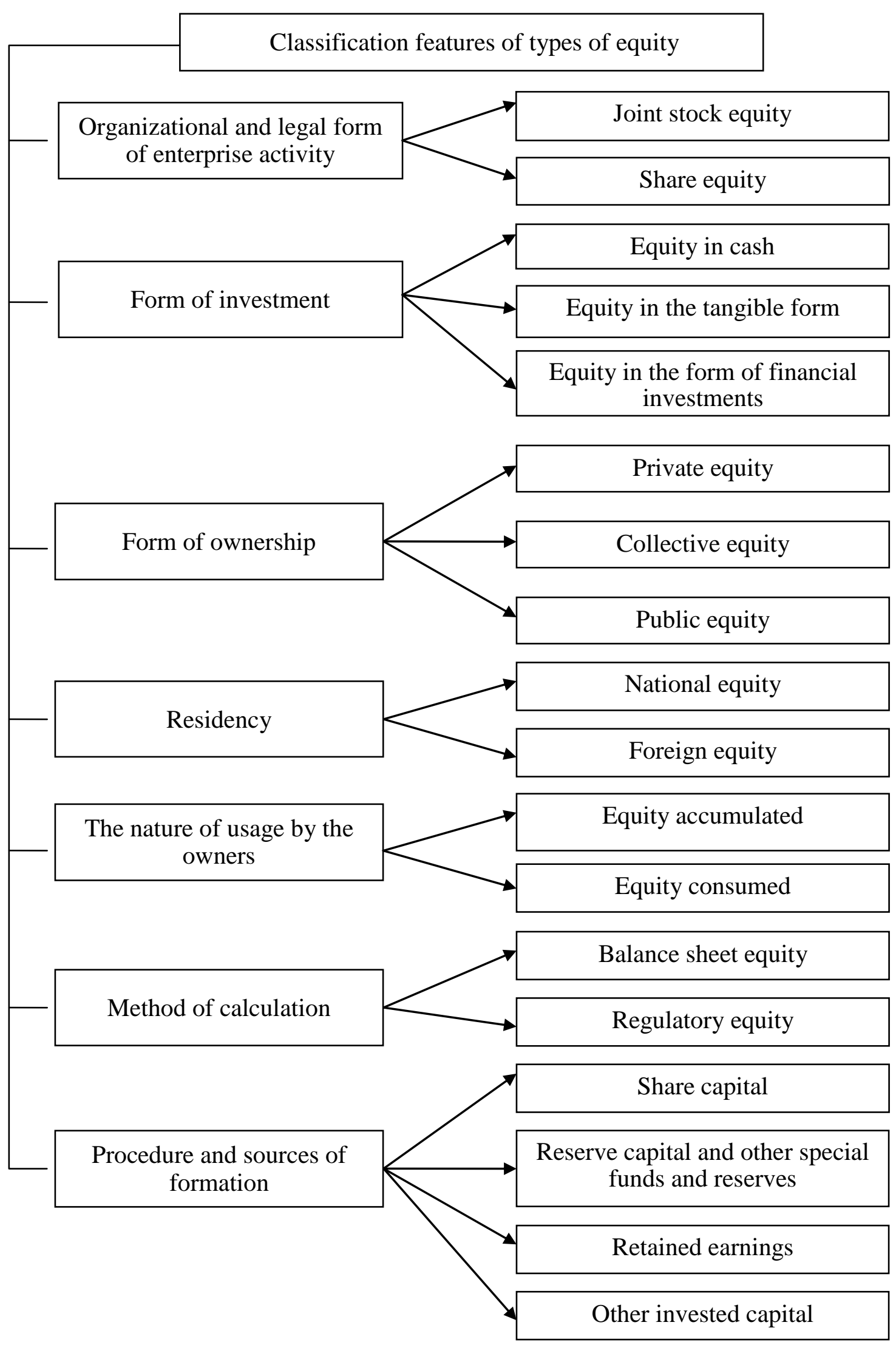

Figure 4. Classification of equity 


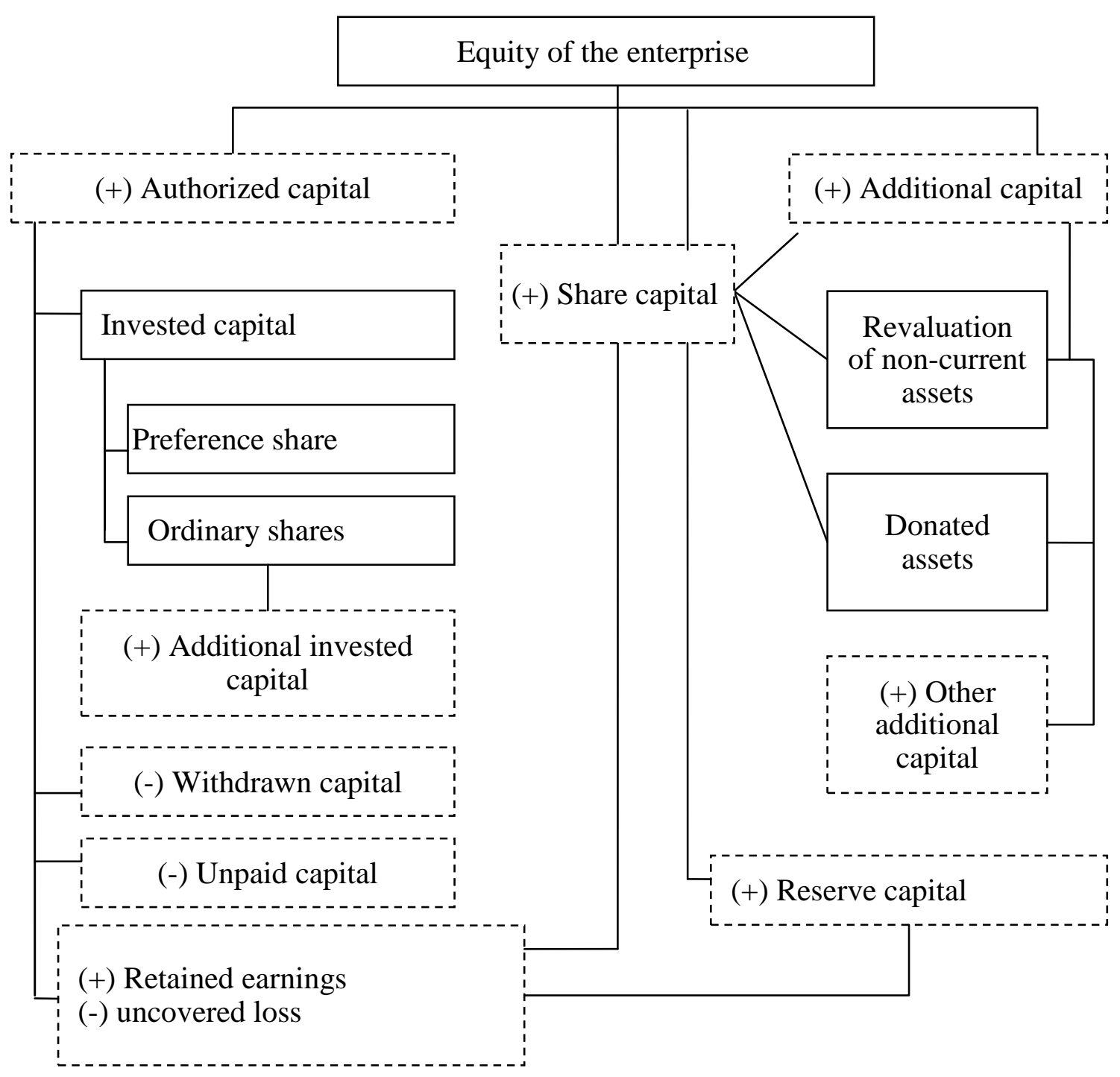

Figure 5. Structure and relationship of individual elements of equity

\subsection{Current state of accounting and control of equity in agricultural enterprises}

Having studied the peculiarities of functioning of agrarian enterprises, it is possible to determine the main tasks of organization of accounting of equity at the enterprise:

- providing data accounting and generalization of information on the state and movement of equity;

- control over the correctness and legality of the formation of equity;

- timely, complete, correct reflection of the size and all changes in equity; 
- control over the rational distribution of profits by the respective funds;

- organization of analytical accounting on equity accounts for timely receipt of reliable information;

- correct recording in the registers of accounting and reporting of the transaction with equity. Equity accounting shows how well the company is provided with the funds for normal functioning. Thus, accounting performs the observation, measurement, recording and control of the amount of equity.

Equity management is the management of the structure and value of sources of financing (liabilities) in order to increase the return on equity and the ability of the enterprise to pay income to creditors and co-owners (shareholders) of the enterprise. Saving and enhancing equity is one of the main tasks of the capital management system because it contributes to the financial stability of the enterprise and capital must always work for the benefit of the enterprise. The result of capital management should be a system of indicators of the state and use of capital, taking into account theoretical generalizations, developed by the enterprise on the basis of its own experience.

The results of the study show that own financial resources for the enterprise are the vital part, without which neither work nor further existence is impossible. Enterprise capital management is closely linked to management decisions, as its size and dynamics are important criteria in determining their optimality. Capital is always a necessary attribute of activity from the moment of creation to its liquidation or reorganization. Therefore, an important characteristic of any enterprise is the effectiveness of its management system.

Methodological principles of formation in accounting of information about equity and disclosure of such information in the financial statements are determined by NP(S)A 1 «General requirements for financial statements», which applies to enterprises, organizations and other legal entities of all forms of ownership (except banks and budgetary institutions).

Accounting is considered as an element of a business information system that generates and interprets the entire database of information flow provided by different systems for effective management. Accounting in general, and accounting for equity in particular, performs the following main tasks:

- providing data accounting and generalization of information on the state and movement of equity; 
- control over the correctness and legality of the formation of equity;

- preservation of property of owners of the enterprise;

- timely, complete, correct reflection of the size and all changes in equity;

- determination of financial results of the enterprise;

- control over the rational distribution of profits by the respective funds;

- organization of analytical accounting on equity accounts for timely receipt of reliable information;

- proper recording in the registers of accounting and reporting of transactions with equity;

- providing users with information to manage the business activity of the enterprise.

Authorized capital accounting reflects the total value of assets that will be received or already received by the enterprise as deposits (contributions) of owners (founders and participants) in the property of the enterprise to ensure the activity of the business entity within the boundaries defined by the constituent documents. These are assets that are transferred to the enterprise in full economic control (ownership, use, disposal) and form the basis of its activities.

To ${ }^{6}$ summarize information on the status and changes in the authorized capital passive account 40 «Registered (share) capital» is assigned. At DB 40 the decrease of the authorized capital is reflected, and at CR 40 it is an increase. The amount of credit balance on account 40 should correspond to the amount of authorized capital recorded in the constituent documents of the company, and is reflected in the balance sheet of the company.

Changes in the authorized capital are carried out in accordance with the procedure established by the current legislation and only after the corresponding changes in the constituent documents are made. The authorized capital may be increased by: additional contributions of participants; proper dividend participants; retained earnings.

The listed options require changes in the founding documents and state registration, as well as the calculation with the participant, to which the amount of his/her contribution to the authorized capital should be returned, the value of part of the property, proportional to his/her contribution to the authorized capital, the share of profit received by the

6 Nakaz Ministerstva Finansiv Ukrainy: pro zatverdzhennia polozhen (standartiv) bukhhalterskoho obliku: 31.01 .99 p. № 87. 
company in the current year. Reduction of the authorized capital is possible at exit, exclusion of the participant, removal of part of the authorized capital.

The reduction of the authorized capital is always connected with the appropriate decision of the owners of the enterprise, which is designed and registered accordingly. The balance in this account must correspond to the amount of authorized capital recorded in the constituent document of the enterprise.

Thus, in accounting, the authorized capital is formed according to the accrual method, when the credit of the account 40 and line 300 of the Balance sheet shows the declared (fixed in the constitional document) the amount of authorized capital, which may be real and not secured (paid) by the assets on the specified date. At the same time, only the actually paid part of the declared authorized capital should be taken into account in the total indicator of the company's equity (the total value of line 380 of the Balance Sheet).

Analytical accounting of authorized capital is conducted by types of capital by each founder, participant, shareholder, co-owner, etc.

The variety of types and forms of enterprises, which currently exists in Ukraine, is conditioned by the legislative consolidation of the diversity of ownership forms, the ways of establishment (formation) of enterprises, the legal regimes of property, which is transferred to the enterprise by its founders. Formation of equity is carried out at the expense of:

- the authorized fund is created at a rate not less than the amount equivalent to 1250 minimum wages, based on the minimum wage rate in force at the time of creation of the company;

- the authorized fund is divided into a certain number of shares of equal minimum value;

- formation of the statutory fund is conducted within one year from the moment of registration of the constitutional documents;

- the amount of the authorized fund in the account must correspond to the amount specified in the constitutional documents;

- changes in the size of the authorized capital are made by the decision of the shareholders meeting with the introduction of changes to the registration card;

- the increase of the authorized capital is carried out by increasing the face value of the shares;

- the decrease of the authorized capital is due to the decrease in the face value of the shares, the loss of the stock of shares. 
An increase in the authorized capital of a joint-stock company by not more than $1 / 3$ may be made by a decision of the board, provided that it is provided by the charter.

Changes to the charter related to the increase of the authorized property must be registered by the body that registered the charter of the joint-stock company after the registration of additionally issued shares. The ways (methods) to increase the authorized capital of a joint-stock company is to increase the number of shares of the existing face value or to increase the face value of the shares. The additional shares are distributed among the shareholders in proportion to their shares in the authorized capital of the joint-stock company. Registration of additional issue of shares is carried out on the basis of the legislation of the Ministry of Finance of Ukraine. The information on additional issue of shares includes:

1) the characteristics of the issuer, i.e. its title, location, date of registration of the joint-stock company, the amount of paid part of the authorized capital and its total volume; ${ }^{7}$

2) data on issue of shares, on additional shares, their face value, shareholders' rights on additional shares, etc.;

3) data on amounts of past periods of cost indexes and depreciation of fixed assets.

If the authorized capital is increased by increasing the face value of the shares, the shares of the previous issues are exchanged for the shares of the new face value according to the number of shares owned by the shareholder. Upon increase of the authorized capital of a joint-stock company by increasing the nominal value of the shares, the registration of the previous issues of shares is canceled and the issue of the shares of the new face value and information on the issue of new shares is required.

The decision to reduce the authorized capital of a joint-stock company is made in the same manner as for the increase of the authorized capital. The share capital is reduced by reducing the face value of the shares or reducing the number of shares by repurchasing a portion of the shares from their owners in order to cancel those shares. According to the decision of the joint-stock company on reduction of the authorized capital, the shares not presented for cancellation shall be declared invalid.

\footnotetext{
${ }^{7}$ Goritskaya N.G. (2002). Osobennosti buhgalterskogo ucheta v sovremennyih usloviyah [Features of accounting in modern conditions]. Kiev: Redaktsiya gazetyi «Buhgalteriya. Nalogi. Biznes», 352 p. ISBN 966-957780-2.
} 
The reduction of the authorized capital of a joint-stock company is allowed after notification of all its creditors in the manner prescribed by law. The creditors of the company have the right to demand early termination or fulfillment of the relevant obligations by the enterprise and compensation of losses. In case of reduction of the authorized capital of a joint-stock company, its size may not be less than the minimum size of the authorized capital specified by the Law of Ukraine "On Business Associations".

When establishing a company and after making decisions on the size of the authorized capital, the total amount of registered authorized capital is recorded in accounting as unpaid capital:

DB 46 «Unpaid capital»..... CR 40 «Registered (share) capital».

According to $\mathrm{NP}(\mathrm{S}) \mathrm{A}$ No. 1, an unpaid capital is the amount of debt of owners (participants) on contributions to the authorized capital.

Such debt arises after fixing its size in the founding document of the enterprise (charter, founding agreement, memorandum) and state registration of this document (additions or amendments to it). Thereafter, the debt is repaid in accordance with the procedure established at the legislative level and/or constitutional documents. The amount of debt is given in parentheses and is calculated when determining the total amount of equity.

The Instruction on the Application of the Plan of Accounts for the Accounting of Assets, Capital, Liabilities and Economic Transactions of Enterprises and Organizations No. 291 provides for all receipts to the authorized capital of enterprises to be displayed using an account 46.

Account 46 «Unpaid capital» is regulatory, intended to summarize information about changes in the composition of unpaid capital of an enterprise. The debit of the account reflects the debt of the founders (participants) on contributions to the authorized capital of the enterprise, as well as the face value of the outstanding shares; on loan it is about repayment of debt on contributions to the authorized capital, i.e. the actual inflow of assets to the enterprise and the face value of the shares paid. The balance of the account 46 «Unpaid Equity» shall correspond to the amount of debt of the founders or shareholders, which shall be repaid within the period specified in the constitutional documents.

The property transferred in kind to the ownership of the enterprise on account of payment of shares, is estimated by agreement of the participants. The basis for the relevant records in accounting are documents certifying the fact of transfer of objects to a joint-stock company. 
Analytical accounting of unpaid capital is maintained by types of outstanding unpaid shares (on joint-stock companies) and by each founder (participant) of the enterprise.

In the regulatory item 360 of the balance sheet, the amount of debt of the founders (participants) on contributions to the authorized capital is given in parentheses, calculated when determining the total equity.

The withdrawn capital remains the regulatory item of the balance. In this item, according to $\mathrm{NP}(\mathrm{S}) \mathrm{A}$ No. 1, companies reflect the actual cost of the shares of their own issue, or the amount of shares purchased by the company from its participants. The state (government-based) and public utilities reflect the transfer of property, according to the Provision on the order of accounting of individual assets and operations of enterprises of state, communal sectors of economy and economic organizations that own and/or use objects of state, communal property, approved by order of the Ministry of Finance of Ukraine dated December 19, 2006.

The Economic Code states that a joint-stock company has the right to repurchase from the shareholders the shares paid by them for the purpose of subsequent cancellation, resale or distribution to employees.

\section{CONCLUSIONS}

In the process of writing of the monograph, the objectives and questions were revealed. The analysis of economic and financial indicators was carried out. Equity plays a paramount role in the financial support of an enterprise. Own financial resources for each enterprise are the vital part without which neither the performance nor the continued existence of the enterprise is impossible. Not without reason, among the classification of total capital, it is the distribution of equity and debt that is in the first place. The own funds available allow the enterprise to use them both at their own discretion, and in some cases in legislatively established directions. It all depends on the source of such financing through the elements of equity. Considering the sources of funding, the following can be noted. Due to the authorized capital it is possible to form a number of non-current assets, that is, it should always be at the disposal of the organization. Its increase and decrease are firmly enshrined in legislation. As a source of financing the authorized capital works in two cases: - at the formation of the enterprise; - in case of additional issue of shares or attraction of additional shares. This means that the authorized capital rarely works as a source of funding. If, during the formation of the 
enterprise, it is the basis for its organization and start-up business, then the attraction of funds in an already existing enterprise pursues the following goals: -attraction of additional capital (in case, when the price of attraction funds from the other source makes it impossible to perform, or it is necessary to attract a significant amount of funds to finance the investment project); - change of the capital's structure. Generally speaking, additional capital is difficult to consider as a source of financing for the activity of the enterprise, because it is formed mainly from the property acquired by the enterprise at the expense of profit or its revaluation, as well as various proceeds enshrined in the legislation of Ukraine. Basically, additional capital adds to the difference between the value of already available assets and the authorized capital. The costs of these funds are also rigidly fixed.

\section{SUMMARY}

The paper summarizes the theoretical and practical aspects of the existing systems of accounting and audit of the equity of enterprises and develops practical recommendations for their improvement in the conditions of market economy, analyzes the mechanism of formation of the main components of equity.

The paper specifies the definition of equity and its components as an economic category, substantiates the concept of accounting for equity at enterprises of various organizational and legal forms of management, proposes to clarify the method of accounting for share capital in agricultural production cooperatives and farm enterprises. The method of accounting of equity in private enterprises is developed. The method of calculating the part of the value of the property received by the founder (participant) upon leaving the Limited Liability Company is substantiated. The directions of improvement of methodology of accounting of additional capital of agrarian enterprises are determined. Suggestions on improvement of forms of reporting on the movement of equity of the enterprise on the basis of optimization of their structure are made.

The basic directions of increase of efficiency of carrying out of audit of equity of the enterprises are defined. The methodology (algorithm) of carrying out of the audit of equity for achievement of the purpose of audit in providing the owner with information on the structure and movement of equity of the enterprise is developed. 


\section{REFERENCES:}

1. Butynets F.F. (2002). Orhanizatsiia bukhhalterskoho obliku: навчальний посібник [Organnization of accounting]. Zhytomyr : PP «Ruta», 591 p. ISBN 966-8059-10-7.

2. Holov S.F. (2000). Bukhhalterskyi oblik ta finansova zvitnist v Ukraini: Navch.-prakt. posibnyk [Accounting and financial reporting in Ukraine]. Dnipropetrovsk, 768 p. ISBN 966-683-033-9.

3. Butynets F.F. (2001). Bukhhalterskyi finansovyi oblik: Pidruchnyk [Financial accounting]. 3-ye vyd., pererob. i dop. Zhytomyr : ZhITI, 672 p. ISBN 966-683-015-3.

4. Butynets F.F. (2003). Bukhhalterskyi finansovyi oblik: Pidruchnyk dlia studentiv spetsialnosti «Oblik i audyt» vyshchykh navch. zakl. [Accounting Financial: A textbook for students of the specialty «Accounting and Auditing» higher education] 5-e vyd., dop. i pererob. Zhytomyr : PP «Ruta», 726 p. ISBN 966-681-012-5.

5. Holtsova S.M., Plikus I.I. (2007). Bukhhalterskyi oblik: navchalnyi posibnyk [Accounting]. 2-he vyd., pererob. i dop. Sumy: VTD «Universytetska knyha», 254 p.

6. Goncharova N.N. (2001). Problemy stanovleniya uchetnoy politiki predpriyatiya $\mathrm{v}$ usloviyakh reformirovaniya bukhgalterskogo ucheta [The problems of the enterprise's accounting policy formation in the circumstances of reformation of accounting]. Rehionalni perspektyvy, $286 \mathrm{p}$.

7. Goritskaya N.G. (2002). Osobennosti buhgalterskogo ucheta v sovremennyih usloviyah [Features of accounting in modern conditions]. Kiev: Redaktsiya gazetyi «Buhgalteriya. Nalogi. Biznes», 352 p. ISBN 966-957780-2.

8. Zakon Ukrainy: pro bukhhalterskyi oblik ta finansovu zvitnist $\mathrm{v}$ Ukraini: vid 16.07.1999 r. №996-XIV (zi zminamy ta dopovnenniamy).

9. Nakaz Ministerstva Finansiv Ukrainy: pro zatverdzhennia polozhen (standartiv) bukhhalterskoho obliku: 31.01 .99 p. №87.

10. Kulichenko O. (2004). Vypustit mene, bud laska [Let me out, please]. Debet-Kredyt -311, p. 25.

\section{Information about the author:} Krukovska O. V.

Candidate of Economic Sciences, Associate Professor, Department of Accounting and Taxation, SHEI «Kherson State Agrarian University», Ukraine ORCID: https://orcid.org/0000-0003-1531-8057 